\title{
PENGEMBANGAN KREATIVITAS KETERAMPILAN PROSES SAINS DALAM ASPEK KEHIDUPAN ORGANISME PADA MATA PELAJARAN IPA SD
}

\author{
Bambang Subali dan Siti Mariyam \\ FMIPA Universitas Negeri Yogyakarta \\ email: b_subali@yahoo.co.id
}

\begin{abstract}
Abstrak: Penelitian ini bertujuan mengetahui seberapa jauh pengembangan kreativitas keterampilan proses sains dalam aspek kehidupan organisme melalui IPA di SD di DIY. Pengumpulan data melalui survei dengan teknik sampel gugus setelah ditetapkan Unit Pelaksana Teknis (UPT) Dinas Pendidikan yang mewakili wilayah perkotaan dan pinggiran. Hasil survei terhadap 400 guru kelas IV dan V serta 1200 grup peserta didik dari 10 UPT di lima kabupaten/kota di DIY menunjukkan hampir semua guru menyatakan pentingnya pembelajaran untuk mengembangkan kreativitas keterampilan proses sains dalam aspek kehidupan kepada peserta didik. Mereka hampir tidak pernah atau jarang membelajarkannya tanpa disertai pemberian contoh. Umumnya mereka sering melakukannya dengan disertai pemberian contoh. Tidak ada guru yang melaporkan pernah mengikuti diklat pengembangan kreativitas.
\end{abstract}

Kata Kunci: kreativitas, keterampilan proses sains, pembelajaran, aktivitas kehidupan

\section{DEVELOPING CREATIVITY OF THE SCIENCE PROCESS SKILL IN THE ORGANISM LIFE ASPECT IN THE ELEMENTARY SCHOOL SCIENCE}

\begin{abstract}
This research is aimed to know how far the development of creativity of science process skills in the life aspect through the science subject in elementary schools in DIY. The data were collected through a survey by employing a group sampling technique after the areas had been determined by the Unit Pelaksana Teknis (UPT) of the education office which represented the city and suburb areas. The results of the survey which involved 400 elementary school teachers of grades IV and V as well as 1200 students from 10 UPT of 5 different regencies/municipalities in DIY show that almost all teachers stated the importance of developing creativity of the science process skill in the life aspect for the students. They hardly ever or seldom taught without giving examples. They often taught by giving examples. There was no teacher who stated that they had ever joined a training to develop the students' creativity.
\end{abstract}

Keywords: creativity, science process skill, learning activity, the life aspect

\section{PENDAHULUAN}

Hakikat belajar Ilmu Pengetahuan Alam (IPA) adalah melatih peserta didik menjadi saintis untuk melakukan investigasi baru terhadap fenomena alam untuk menemukan produk ilmiah yang baru melalui proses ilmiah berlandaskan sikap ilmiah. Produk ilmiah baru tersebut berupa fakta, konsep, generalisasi, prinsip, teori dan hukum (Carin \& Sund, 1989:6). Proses ilmiah tersebut melibatkan berbagai keterampilan proses sains seperti keterampilan mengamati dan mengoleksi data, melakukan pengukuran, mengorganisasikan data, menglasifikasi, merumuskan hipotesis, membuat prediksi, melakukan percobaan, menganalisis data, mem- buat inferensi (menarik simpulan), membuat model, dan berkomunikasi secara ilmiah. Jika proses ilmiah tersebut disusun dalam suatu urutan tertentu dan digunakan untuk memecahkan suatu permasalahan yang dihadapi, rangkaian proses ilmiah itu menjadi suatu metode ilmiah (Towle, 1989:16-31). Agar aspek keterampilan proses sains dapat dikuasai dengan baik oleh peserta didik, perlu diajarkan sejak dini.

Lampiran Peraturan Menteri Pendidikan nasional Nomor 22 Tahun 2006 tentang Standar Isi Pendidikan Dasar dan Menengah (Depdiknas, 2006:484) menyuratkan bahwa IPA berhubungan dengan cara mencari tahu tentang alam secara sistematis. IPA bukan hanya pe- 
nguasaan kumpulan pengetahuan yang berupa fakta-fakta, konsep-konsep, atau prinsip-prinsip saja tetapi juga merupakan suatu proses penemuan. Pembelajaran IPA sebaiknya dilaksanakan secara inkuiri ilmiah untuk menumbuhkan kemampuan berpikir, bekerja dan bersikap ilmiah serta mengkomunikasikannya sebagai aspek penting kecakapan hidup. Pembelajaran IPA di SD/MI menekankan pada pemberian pengalaman belajar secara langsung melalui penggunaan dan pengembangan keterampilan proses dan sikap ilmiah sehingga peserta didik memiliki kemampuan yang di antaranya adalah memiliki keterampilan proses untuk menyelidiki alam sekitar, memecahkan masalah dan membuat keputusan dengan menerapkan keterampilan proses sains secara ilmiah sehingga berkembang kemampuan berpikir kreatif pada diri peserta didik.

Chiapetta (1997:22) menyatakan bahwa dalam pembelajaran sains peserta didik harus diarahkan aktif melakukan inquiri dengan menerapkan berbagai strategi dan teknik untuk membantu peserta didik berpikir dan memperoleh sesuatu melalui berbagai pertanyaan, kesenjangan, keterampilan proses, aktivitas deduktif dan induktif, pencarian informasi, dan pemecahan masalah. Pembelajaran inkuiri akan melatih peserta didik mampu melakukan investigasi (Edwards, 1997:18). Oleh karena itu, pembelajaran inkuiri sudah sewajarnya dimulai sejak SD/MI.

Dalam konteks pengembangan kreativitas pada diri peserta didik, Cochran \& Lytle (2006:668-693) menyatakan perlunya untuk menciptakan lingkungan yang kondusif yang benar-benar mendukung kegiatan belajar. Peserta didik dikondisikan agar lebih dimungkinkan aktif dengan gagasan mereka, bukan sekedar menjawab dengan cara dihafal tanpa pikir. Miller (2005:65) membuat definisi sederhana tentang kreatif yaitu sesuatu yang bukan hasil duplikasi/tiruan (copy) dikategorikan sesuatu yang kreatif. Dengan demikian, kreativitas keterampilan proses sains dapat diajarkan dengan meminta peserta didik berinisiatif sendiri dengan atau tanpa diberi contoh terlebih dahulu. Cara mengembangkan kemampuan berpikir kreatif dapat diwujudkan dengan melatih peserta didik melakukan (1) substitusi, (2) kombinasi, (3) penyesuaian pada situasi lain, (4) modifikasi atau penambahan, (5) penempatan sesuatu untuk penggunaan yang lain, (6) eliminasi atau pengurangan, dan (7) penyusunan kembali atau pemutarbalikan (Michalko, 2000:18-21).

Berkaitan dengan itu, penelitian ini bertujuan untuk mengetahui seberapa jauh pengembangan kreativitas keterampilan proses sains khususnya yang berkaitan dengan aspek kehidupan organisme di SD di Daerah Istimewa Yogyakarta.

\section{METODE}

Penelitian dilakukan dengan menggunakan metode survei di lima kabupaten/kota di DIY dengan pengambilan sampel secara gugus (cluster sampling) di tiap kabupaten/kota ditentukan dua unit pelaksana teknis (UPT) yang memiliki karakteristik spesifik wilayah keterkaitannya dengan kedekatannya dengan pusat kota agar menggambarkan keterwakilan populasi guru dan peserta didik di DIY.

Dalam hal ini, untuk Kota Yogyakarta ditetapkan UPT Yogyakarta Barat (yang didomininasi wilayah pusat kota) dan Yogyakarta Timur (yang didomininasi wilayah pinggiran), Kabupaten Sleman diambil UPT Sleman (yang didominasi wilayah pusat kota) dan UPT Kalasan (yang didomininasi wilayah pinggiran), Kabupaten Bantul yaitu UPT Bantul (yang didominasi wilayah pusat kota) dan UPT Banguntapan (yang didominasi wilayah pinggiran), Kabupaten Gunungkidul diambil UPT Wonosari (yang didominasi wilayah pusat kota) dan UPT Panggang (yang didominasi wilayah pedesaan), dan Kabupaten Kulonprogo diambil UPT Pengasih (yang didominasi wilayah pusat kota) dan UPT Kalibawang (yang didominasi wilayah pedesaan). Dari tiap UPT dilakukan pengundian sekolah untuk mengambil 20 guru kelas IV dan dan 20 guru kelas $\mathrm{V}$ untuk dijadikan responden dalam penelitian ini. Untuk triangulasi dari tiap sekolah sampel diambil tiga kelompok peserta didik dari kelas V dan VI dijadikan responden dalam penelitian ini. 
Instrumen berupa kuesioner yang memuat aspek keterampilan proses sains yang diharapkan sudah diajarkan di SD, yaitu berupa aspek-aspek keterampilan proses sains yang termasuk ke dalam keterampilan dasar dan keterampilan mengolah/memroses. Adapun acuan perumusannya adalah learning continuum keterampilan proses sains yang dikembangkan dalam disertasi Bambang Subali tahun 2009. Hasil perumusan tersebut dijadikan kisi-kisi penyusunan instrumen dan ditelaah oleh dua pakar pendidikan biologi. Kuesioner untuk guru dan peserta didik ditelaah oleh 4 pengawas SD.

Kuesioner untuk mengungkap persepsi guru yang menyangkut nilai penting pengembangan kreativitas tiap aspek keterampilan proses sains yang berkaitan dengan aspek kehidupan organisme beserta implementasinya dalam kegiatan pembelajaran. Adapun kuesioner untuk peserta didik kelas V dan VI adalah berkaitan dengan implementasinya dalam pembelajaran sejak mereka belajar IPA.

Banyaknya butir yang terdapat di dalam kuesioner guru tentang pengembangan kreativitas aspek keterampilan keterampilan proses sains yang berkaitan dengan aktivitas kehidupan organisme adalah sebagai berikut. Keterampilan dasar untuk aspek (1) melakukan pengamatan 7 butir; (2) merekam data/informasi 9 butir; (3) mengikuti instruksi 4 butir; (4) mengklasifikasi 3 butir; (5) melakukan pengukuran 8 butir; (6) melakukan manipulasi gerak 2 butir; dan (7) menerapkan prosedur penggunaan peralatan 14 butir. Keterampilan mengolah/memroses untuk aspek (1) menginferensi 7 butir; (2) memprediksi 4 butir; dan (3) dan menyeleksi prosedur 4 butir.

Banyaknya butir yang terdapat di dalam kuesioner peserta didik tentang pengembangan kreativitas aspek keterampilan keterampilan proses sains yang berkaitan dengan aktivitas kehidupan organisme adalah sebagai berikut. Keterampilan dasar untuk aspek (1) melakukan pengamatan 7 butir; (2) merekam data/informasi 6 butir; (3) mengikuti instruksi 4 butir; (4) mengklasifikasi 3 butir; (5) melakukan pengukuran 8 butir; (6) melakukan manipulasi gerak 2 butir; dan (7) menerapkan prosedur penggunaan peralatan 14 butir. Keterampilan mengolah/memroses untuk aspek (1) menginferensi 7 butir; (2) memprediksi 4 butir; dan (3) dan menyeleksi prosedur 4 butir.

Data dianalisis secara deskriptif dengan membuat kategorisasi jawaban yang diberikan subjek penelitian. Kategorisasi setiap aspek keterampilan sains diperoleh dengan mengalikan banyaknya butir dikalikan dengan skala kemudian dibagi dengan banyaknya kategori yang ditetapkan. Untuk kategorisasi nilai penting menurut persepsi guru seperti pada kategori berikut.

\section{Kategorisasi Nilai Penting Menurut Persepsi Guru Kategorisasi}

\begin{tabular}{lccccccc}
\hline Jumlah butir & 2 & 3 & 4 & 7 & 8 & 9 & 14 \\
\hline Batas masuk kategori kurang penting & 67 & 100 & 133 & 233 & 267 & 300 & 467 \\
Batas masuk kategori penting & 93 & 140 & 187 & 327 & 373 & 420 & 653 \\
\hline
\end{tabular}

Kategorisasi Pelaksanaan Pembelajaran Menurut Persepsi Guru Kategorisasi

\begin{tabular}{lccccccc}
\hline Jumlah butir & 2 & 3 & 4 & 7 & 8 & 9 & 14 \\
\hline Batas masuk kategori jarang & 67 & 100 & 133 & 233 & 267 & 300 & 467 \\
Batas masuk kategori sering & 93 & 140 & 187 & 327 & 373 & 420 & 653 \\
\hline
\end{tabular}




\section{Kategorisasi Pelaksanaan Pembelajaran Menurut Persepsi Peserta Didik Kategorisasi}

\begin{tabular}{lrrrrrrr}
\hline Jumlah butir & 2 & 3 & \multicolumn{1}{c}{4} & \multicolumn{1}{c}{6} & \multicolumn{1}{c}{7} & \multicolumn{1}{c}{8} & \multicolumn{1}{c}{14} \\
\hline Batas masuk kategori hampir tidak pernah & $<60$ & $<90$ & $<120$ & $<180$ & $<210$ & $<240$ & $<420$ \\
Batas masuk kategori pernah & $\mathbf{6 0}$ & $\mathbf{9 0}$ & $\mathbf{1 2 0}$ & $\mathbf{1 8 0}$ & $\mathbf{2 1 0}$ & $\mathbf{2 4 0}$ & $\mathbf{4 2 0}$ \\
\hline
\end{tabular}

\section{HASIL DAN PEMBAHASAN}

Setelah dilakukan pengumpulan data dari 20 guru Kelas IV dan 20 guru Kelas V juga 60 peserta didik Kelas V dan 60 peserta didik Kelas VI dari tiap-tiap UPT di lima kabupaten/kota di DIY diperoleh hasil sebagai berikut.

\section{Hasil}

\section{Persepsi Guru}

Persepsi guru kelas IV terhadap nilai pentingnya pengembangan keterampilan proses sains yang berkaitan dengan aspek kehidupan organisme disajikan pada Tabel 1 sedangkan untuk guru kelas V disajikan pada Tabel 2.

Hampir semua guru sampel, yakni sebanyak 400 guru, menyatakan bahwa pengembangan keterampilan proses sains yang berkaitan dengan aspek kehidupan organisme penting untuk diajarkan pada peserta didik. Aspek keterampilan proses sains yang termasuk keterampilan dasar yakni meliputi (1) keterampilan melakukan pengamatan; (2) merekam data/informasi; (3) mengikuti instruksi; (4) mengklasifikasi; (5) melakukan pengukuran; (6) melakukan manipulasi gerak; dan (7) menerapkan prosedur penggunaan peralatan. Adapun aspek keterampilan proses sains yang termasuk keterampilan mengolah/memroses yaitu (1) keterampilan menginverensi; (2) memprediksi; dan (3) menyeleksi prosedur. Masing-masing aspek diungkap dengan sejumlah butir sesuai dengan indikator yang dikembangkan dari tiap aspek keterampilan yang bersangkutan.

Sebagian guru kelas $\mathrm{V}$ yang menilai kurang penting mengembangkan kreativitas keterampilan dasar yaitu dalam hal keterampilan merekam informasi adalah guru berasal dari UPT Wonosari. Kemudian guru kelas V yang menilai kurang penting mengembangkan kreativitas keterampilan dasar yaitu dalam menerap- kan prosedur penggunaan peralatan juga guru dari UPT Wonosari ditambah dengan guru dari UPT Pengasih dan Kalibawang. Guru kelas V yang menilai kurang penting mengembangkan kreativitas keterampilan mengolah/memroses yaitu dalam hal keterampilan menyeleksi prosedur juga berasal dari UPT Wonosari.

Pernyataan guru yang berkaitan dengan implementasi pembelajaran untuk mengembangkan keterampilan proses sains yang berkaitan dengan aktivitas kehidupan organisme disajikan dalam Tabel 3, 4, 5 dan 6.

Tabel 3 dan Tabel 4 menunjukkan guru menyatakan bahwa dalam hal membelajarkan kreativitas keterampilan proses sains yang dilakukan tanpa memberikan contoh. Kedua tabel menunjukkan bahwa guru hampir tidak pernah atau jarang membelajarkan kreativitas keterampilan proses sains tanpa disertai dengan pemberian contoh. Bahkan, guru kelas IV dari UPT Wonosari menyatakan hampir tidak pernah mengajarkannya, baik untuk aspek keterampilan dasar maupun keterampilan mengolah/memroses.

Guru menyatakan bahwa dalam hal membelajarkan kreativitas keterampilan proses sains yang dilakukan dengan disertai pemberian contoh terlebih dahulu. Kedua tabel menunjukkan pemberian contoh tersebut dilakukan hampir pada semua keterampilan proses sains sebagai upaya untuk mengembangkan kreativitas. Jika dibandingkan antara Tabel 5 dan Tabel 6, pernyataan sering melakukannya yang dikemukakan guru lebih banyak muncul pada Tabel 6, yakni berasal dari guru kelas V. Bila Tabel 6 diperhatikan lebih lanjut, guru dari UPT Piyungan, Panggang, dan Pengasih menyatakan banyak aspek keterampilan proses sains yang jarang diajarkan untuk pengembangan kreativitas peserta didik. Tabel 6 juga menunjukkan bahwa 
keterampilan dasar khususnya dalam hal keterampilan melakukan pengukuran dan keterampilan penerapkan prosedur penggunaan peralatan termasuk keterampilan yang jarang diajarkan oleh guru kelas $\mathrm{V}$ meskipun disertai pemberian contoh sekalipun. Hal yang sama juga terjadi pada pengembangan kreativitas keterampilan proses sains yang berkaitan dengan keterampilan mengolah/memroses yakni dalam hal memilih prosedur.

Jika dikaitkan dengan jenis diklat yang diikuti sebagaimana tersaji pada Tabel $7 \mathrm{a}$ dan $7 \mathrm{~b}$ menunjukkan bahwa guru sampel yang paling sedikit mengikuti diklat tidak ada keterkaitan antara pengalaman tersebut dengan pengem- bangan kreativitas. Mencermati jenis pendidikan dan latihan (diklat) yang telah diikuti guru sampel, tidak ada guru yang menuliskan secara khusus pernah mengikuti diklat pengembangan kreativitas dalam pembelajaran. Tabel $7 \mathrm{a}$ dan $7 \mathrm{~b}$ menunjukkan bahwa guru sampel yang paling sedikit mengikuti diklat adalah guru kelas IV dan V dari UPT Wonosari dan guru kelas IV UPT Panggang. Guru kelas IV dan kelas V dari UPT Kalibawang walau relatif cukup banyak yang pernah mengikuti diklat namun lebih banyak yang menyatakan jarang membelajarkan keterampilan proses sains kepada peserta didik untuk mengembangkan kreativitas.

Tabel 1. Persepsi Guru kelas IV IPA SD di DIY terhadap Nilai Penting Pengembangan Kreativitas Keterampilan Proses Sains yang Berkaitan dengan Aspek Kehidupan Organisme

\begin{tabular}{ccccccccccc}
\hline & \multicolumn{8}{c}{ Wilayah Unit Pelaksana Teknis } \\
\cline { 2 - 10 } $\begin{array}{c}\text { Aspek Keterampilan Prose } \\
\text { Sains }\end{array}$ & \begin{tabular}{c} 
Kogya \\
\cline { 2 - 9 }
\end{tabular} & Kb. Sleman & Kb. Bantul & \multicolumn{2}{c}{ Kb. Gk } & \multicolumn{2}{c}{ Kb.Kp } \\
\cline { 2 - 10 } & Yb & Yt & Sl & Kal & Btl & Piyu & Wnsr & Pang & Peng & Klbw \\
\hline
\end{tabular}

\section{Keterampilan Dasar}

$\begin{array}{lllllllllll}\text { A. Melakukan pengamatan } & \mathrm{P} & \mathrm{P} & \mathrm{P} & \mathrm{P} & \mathrm{P} & \mathrm{P} & \mathrm{P} & \mathrm{P} & \mathrm{P} & \mathrm{P} \\ \text { B. Merekam data/informasi } & \mathrm{P} & \mathrm{P} & \mathrm{P} & \mathrm{P} & \mathrm{P} & \mathrm{P} & \mathrm{P} & \mathrm{P} & \mathrm{P} & \mathrm{P} \\ \text { C. Mengikuti instruksi } & \mathrm{P} & \mathrm{P} & \mathrm{P} & \mathrm{P} & \mathrm{P} & \mathrm{P} & \mathrm{P} & \mathrm{P} & \mathrm{P} & \mathrm{P} \\ \text { D. Mengklasifikasi } & \mathrm{P} & \mathrm{P} & \mathrm{P} & \mathrm{P} & \mathrm{P} & \mathrm{P} & \mathrm{P} & \mathrm{P} & \mathrm{P} & \mathrm{P} \\ \text { E. Melakukan pengukuran } & \mathrm{P} & \mathrm{P} & \mathrm{P} & \mathrm{P} & \mathrm{P} & \mathrm{P} & \mathrm{P} & \mathrm{P} & \mathrm{P} & \mathrm{P} \\ \text { F. Melakukan manipulasi gerak } & \mathrm{P} & \mathrm{P} & \mathrm{P} & \mathrm{P} & \mathrm{P} & \mathrm{P} & \mathrm{P} & \mathrm{P} & \mathrm{P} & \mathrm{P} \\ \text { G. Menerapkan prosedur } & \mathrm{P} & \mathrm{P} & \mathrm{P} & \mathrm{P} & \mathrm{P} & \mathrm{P} & \mathrm{P} & \mathrm{P} & \mathrm{P} & \mathrm{P}\end{array}$

II. Keterampilan Mengolah/ Memroses

\begin{tabular}{|c|c|c|c|c|c|c|c|c|c|c|}
\hline A. Menginferensi & $P$ & $P$ & $P$ & $P$ & $P$ & $P$ & $P$ & $P$ & $P$ & $\mathrm{P}$ \\
\hline B. Memprediksi & $P$ & $P$ & $P$ & $\mathrm{P}$ & $P$ & $\mathrm{P}$ & $\mathrm{P}$ & $\mathrm{P}$ & $\mathrm{P}$ & $\mathrm{P}$ \\
\hline C. Menyeleksi prosedur & $\mathrm{P}$ & $P$ & $\mathrm{P}$ & $P$ & $P$ & $\mathrm{P}$ & $\mathrm{P}$ & $\mathrm{P}$ & $\mathrm{P}$ & $\mathrm{P}$ \\
\hline
\end{tabular}

Keterangan Kategori:
P: Penting;
KP: Kurang Penting;
HTP: Hampir Tidak Penting

Keterangan Wilayah:

$\begin{array}{llllll}\text { KT. YOGYA } & \text { : Kota Yogyakarta; } & \text { YG } & \text { : Yogyakarta Barat; } & \text { YT } & \text { : Yogyakarta Timur } \\ \text { KB. SLEMAN } & \text { : Kabupaten Sleman; } & \text { SL } & \text { : Sleman; } & \text { KAL } & \text { : Kalasan } \\ \text { KB. BANTUL : Kabupaten Bantul; } & \text { BTL } & \text { : Bantul; } & \text { PIYU } & \text { : Piyungan } \\ \text { KB. GK } & \text { : Kabupaten Gunungkidul; } & \text { WNSR } & \text { : Wonosari; } & \text { PANG : Panggang } \\ \text { KB. KP } & \text { : Kabupaten Kulonprogo; } & \text { PENG } & \text { : Pengasih; } & \text { KLBW : Kalibawang }\end{array}$


Tabel 2. Persepsi Guru kelas V IPA SD di DIY terhadap Nilai penting Pengembangan Kreativitas Keterampilan Proses Sains yang Berkaitan dengan Aspek Kehidupan Organisme

\begin{tabular}{|c|c|c|c|c|c|c|c|c|c|c|}
\hline \multirow{3}{*}{$\begin{array}{l}\text { Aspek Keterampilan Proses } \\
\text { Sains }\end{array}$} & \multicolumn{10}{|c|}{ Wilayah Unit Pelaksana Teknis } \\
\hline & \multicolumn{2}{|c|}{ Kt. Yogya } & \multicolumn{2}{|c|}{ Kb. Sleman } & \multicolumn{2}{|c|}{ Kb. Bantul } & \multicolumn{2}{|c|}{ Kb. Gk } & \multicolumn{2}{|c|}{ Kb.Kp } \\
\hline & $\mathbf{Y B}$ & $\mathbf{Y t}$ & SI & Kal & Btl & Piyu & Wnsr & Pang & Peng & Klbw \\
\hline \multicolumn{11}{|l|}{ I. Keterampilan Dasar } \\
\hline A. Melakukan pengamatan & $P$ & $P$ & $\mathrm{P}$ & $\mathrm{P}$ & $P$ & $P$ & $P$ & $\mathrm{P}$ & $\mathrm{P}$ & $\mathrm{P}$ \\
\hline B. Merekam data/informasi & $\mathrm{P}$ & $P$ & $\mathrm{P}$ & $\mathrm{P}$ & $\mathrm{P}$ & $\mathrm{P}$ & KP & $\mathrm{P}$ & $\mathrm{P}$ & $\mathrm{P}$ \\
\hline C. Mengikuti instruksi & $\mathrm{P}$ & $P$ & $\mathrm{P}$ & $\mathrm{P}$ & $\mathrm{P}$ & $\mathrm{P}$ & $\mathrm{P}$ & $P$ & $\mathrm{P}$ & $\mathrm{P}$ \\
\hline D. Mengklasifikasi & $P$ & $\mathrm{P}$ & $\mathrm{P}$ & $P$ & $\mathrm{P}$ & $\mathrm{P}$ & $\mathrm{P}$ & $\mathrm{P}$ & $\mathrm{P}$ & $\mathrm{P}$ \\
\hline E. Melakukan pengukuran & $P$ & $P$ & $\mathrm{P}$ & $P$ & $P$ & $P$ & $P$ & $P$ & $\mathrm{P}$ & $P$ \\
\hline $\begin{array}{l}\text { F. Melakukan manipulasi } \\
\text { gerak }\end{array}$ & $\mathrm{P}$ & $\mathrm{P}$ & $\mathrm{P}$ & $\mathrm{P}$ & $\mathrm{P}$ & $\mathrm{P}$ & $\mathrm{P}$ & $\mathrm{P}$ & $\mathrm{P}$ & $\mathrm{P}$ \\
\hline $\begin{array}{l}\text { G. Menerapkan prosedur } \\
\text { penggunaan peralatan }\end{array}$ & $\mathrm{P}$ & $P$ & KP & $P$ & $\mathrm{P}$ & $\mathrm{P}$ & KP & $P$ & KP & $\mathrm{KP}$ \\
\hline \multicolumn{11}{|c|}{ II. Keterampilan Mengolah/ Memroses } \\
\hline A. Menginferensi & $\mathrm{P}$ & $\mathrm{P}$ & $\mathrm{P}$ & $\mathrm{P}$ & $\mathrm{P}$ & $\mathrm{P}$ & $\mathrm{P}$ & $\mathrm{P}$ & $\mathrm{P}$ & KP \\
\hline B. Memprediksi & $\mathrm{KP}$ & $P$ & $\mathrm{P}$ & $P$ & $P$ & $P$ & $\mathrm{P}$ & $P$ & $P$ & $\mathrm{P}$ \\
\hline C. Menyeleksi prosedur & $\mathrm{P}$ & $P$ & $\mathrm{P}$ & $P$ & $P$ & $P$ & KP & $\mathrm{P}$ & $\mathrm{P}$ & $\mathrm{P}$ \\
\hline
\end{tabular}

Keterangan Kategori:

P: Penting;

KP: Kurang Penting;

HTP: Hampir Tidak Penting

Keterangan Wilayah:

$\begin{array}{llllll}\text { Kt. Yogya } & \text { : Kota Yogyakarta; } & \text { Yg } & \text { : Yogyakarta Barat; } & \text { Yt } & \text { : Yogyakarta Timurkb. } \\ \text { Sleman } & \text { : Kabupaten Sleman; } & \text { Sl } & \text { : Sleman; } & \text { Kal } & \text { : Kalasan } \\ \text { Kb. Bantul } & : \text { Kabupaten Bantul; } & \text { Btl } & \text { : Bantul; } & \text { Piyu } & \text { : Piyungan } \\ \text { Kb. Gk } & : \text { Kabupaten Gunungkidul; } & \text { Wnsr } & \text { : Wonosari; } & \text { Pang } & \text { : Panggang } \\ \text { Kb. Kp } & \text { : Kabupaten Kulonprogo; } & \text { Peng } & \text { : Pengasih; } & \text { Klbw } & \text { : Kalibawang }\end{array}$

Tabel 3. Pernyataan Guru Kelas IV IPA SD di DIY tentang Pembelajaran Pengembangan Kreativitas Keterampilan Proses Sains yang Berkaitan dengan Aspek Kehidupan Organisme yang Telah Diselenggarakan Tanpa Disertai Pemberian Contoh

\begin{tabular}{|c|c|c|c|c|c|c|c|c|c|c|}
\hline \multirow{3}{*}{$\begin{array}{l}\text { Aspek Keterampilan } \\
\text { Proses Sains }\end{array}$} & \multicolumn{10}{|c|}{ Wilayah Unit Pelaksana Teknis } \\
\hline & \multicolumn{2}{|c|}{ Kt. Yogya } & \multicolumn{2}{|c|}{ Kb. Sleman } & \multicolumn{2}{|c|}{ Kb. Bantul } & \multicolumn{2}{|c|}{ Kb. Gk } & \multicolumn{2}{|c|}{ Kb.Kp } \\
\hline & $\mathbf{Y b}$ & $\mathbf{Y t}$ & SI & Kal & Btl & Piyu & Wnsr & Pang & Peng & Klbw \\
\hline \multicolumn{11}{|l|}{ I. $\quad$ Keterampilan Dasar } \\
\hline A. Melakukan pengamatan & $\mathrm{J}$ & $\mathrm{J}$ & $\mathrm{J}$ & НTP & $\mathrm{J}$ & НTP & HTP & HTP & $\mathrm{J}$ & $\mathrm{J}$ \\
\hline B. Merekam data/informasi & $\mathrm{J}$ & $\mathrm{J}$ & HTP & HTP & HTP & HTP & HTP & HTP & HTP & $\mathrm{J}$ \\
\hline C. Mengikuti instruksi & HTP & HTP & HTP & HTP & HTP & HTP & HTP & HTP & HTP & HTP \\
\hline D. Mengklasifikasi & $\mathrm{J}$ & $\mathrm{J}$ & HTP & НTP & HTP & HTP & HTP & HTP & $\mathrm{J}$ & $\mathrm{J}$ \\
\hline E. Melakukan pengukuran & $\mathrm{J}$ & HTP & HTP & HTP & HTP & HTP & HTP & HTP & НTP & HTP \\
\hline $\begin{array}{l}\text { F. Melakukan manipulasi } \\
\text { gerak }\end{array}$ & $\mathrm{J}$ & HTP & $\mathrm{J}$ & $\mathrm{J}$ & $\mathrm{J}$ & HTP & HTP & $\mathrm{J}$ & $\mathrm{J}$ & $\mathrm{J}$ \\
\hline $\begin{array}{l}\text { G. Menerapkan prosedur } \\
\text { penggunaan peralatan }\end{array}$ & $\mathrm{J}$ & HTP & $\mathrm{J}$ & HTP & HTP & HTP & HTP & HTP & HTP & HTP \\
\hline \multicolumn{11}{|c|}{ II. Keterampilan Mengolah/ Memroses } \\
\hline A. Menginferensi & $\mathrm{J}$ & $\mathrm{J}$ & $\mathrm{J}$ & $\mathrm{J}$ & HTP & HTP & HTP & HTP & HTP & $\mathrm{J}$ \\
\hline B. Memprediksi & HTP & HTP & HTP & НTP & НTP & HTP & HTP & HTP & $\mathrm{J}$ & $\mathrm{J}$ \\
\hline C. Menyeleksi prosedur & $\mathrm{J}$ & $\mathrm{J}$ & $\mathrm{J}$ & HTP & HTP & HTP & НTP & НTP & HTP & HTP \\
\hline
\end{tabular}


Keterangan Kategori:
S: Sering;
J: Jarang;
HTP: Hampir Tidak Pernah

Keterangan Wilayah:

$\begin{array}{llllll}\text { Kt. Yogya } & \text { : Kota Yogyakarta; } & \text { Yg } & \text { : Yogyakarta Barat; } & \text { Yt } & \text { : Yogyakarta Timur } \\ \text { Kb. Sleman } & \text { : Kabupaten Sleman; } & \text { Sl } & \text { : Sleman; } & \text { Kal } & \text { : Kalasan } \\ \text { Kb. Bantul } & \text { : Kabupaten Bantul; } & \text { Btl } & \text { : Bantul; } & \text { Piyu } & \text { : Piyungan } \\ \text { Kb. Gk } & \text { : Kabupaten Gunungkidul; } & \text { Wnsr } & \text { : Wonosari; } & \text { Pang } & \text { : Panggang } \\ \text { Kb. Kp } & \text { : Kabupaten Kulonprogo; } & \text { Peng } & \text { : Pengasih; } & \text { Klbw } & \text { : Kalibawang }\end{array}$

Tabel 4. Pernyataan Guru Kelas V IPA SD di DIY tentang Pembelajaran Pengembangan Kreativitas Keterampilan Proses Sains yang Berkaitan dengan Aspek Kehidupan Organisme yang Telah Diselenggarakan Tanpa Disertai Pemberian Contoh

\begin{tabular}{|c|c|c|c|c|c|c|c|c|c|c|}
\hline \multirow{3}{*}{$\begin{array}{l}\text { Aspek Keterampilan } \\
\text { Proses Sains }\end{array}$} & \multicolumn{10}{|c|}{ Wilayah Unit Pelaksana Teknis } \\
\hline & \multicolumn{2}{|c|}{ Kt. Yogya } & \multicolumn{2}{|c|}{ Kb. Sleman } & \multicolumn{2}{|c|}{ Kb. Bantul } & \multicolumn{2}{|c|}{ Kb. Gk } & \multicolumn{2}{|c|}{ Kb.Kp } \\
\hline & Yb & Yt & SI & Kal & Btl & Piyu & Wnsr & Pang & Peng & Klbw \\
\hline \multicolumn{11}{|c|}{ I. Keterampilan Dasar } \\
\hline $\begin{array}{l}\text { A. Melakukan } \\
\text { pengamatan }\end{array}$ & HTP & HTP & HTP & HTP & $\mathrm{J}$ & HTP & $\mathrm{J}$ & HTP & $\mathrm{J}$ & $\mathrm{J}$ \\
\hline $\begin{array}{l}\text { B. Merekam } \\
\text { data/informasi }\end{array}$ & $\mathrm{J}$ & $\mathrm{J}$ & HTP & HTP & $\mathrm{J}$ & HTP & HTP & HTP & $\mathrm{J}$ & $\mathrm{J}$ \\
\hline $\begin{array}{l}\text { C. Mengikuti } \\
\text { instruksi }\end{array}$ & $\mathrm{J}$ & $\mathrm{J}$ & $\mathrm{J}$ & HTP & $\mathrm{J}$ & HTP & HTP & $\mathrm{J}$ & $\mathrm{J}$ & $\mathrm{J}$ \\
\hline D. Mengklasifikasi & $\mathrm{J}$ & $\mathrm{J}$ & $\mathrm{J}$ & HTP & $\mathrm{J}$ & HTP & HTP & $\mathrm{J}$ & $\mathrm{J}$ & $\mathrm{J}$ \\
\hline $\begin{array}{l}\text { E. Melakukan } \\
\text { pengukuran }\end{array}$ & HTP & $\mathrm{J}$ & $\mathrm{J}$ & HTP & HTP & HTP & HTP & HTP & HTP & $\mathrm{J}$ \\
\hline $\begin{array}{l}\text { F. Melakukan } \\
\text { manipulasi gerak }\end{array}$ & HTP & HTP & HTP & $\mathrm{J}$ & $\mathrm{J}$ & HTP & $\mathrm{J}$ & HTP & $\mathrm{J}$ & $\mathrm{J}$ \\
\hline $\begin{array}{l}\text { G. Menerapkan } \\
\text { prosedur } \\
\text { penggunaan } \\
\text { peralatan }\end{array}$ & HTP & $\mathrm{J}$ & $\mathrm{J}$ & HTP & HTP & HTP & $\mathrm{J}$ & HTP & HTP & $\mathrm{J}$ \\
\hline \multicolumn{11}{|c|}{ II. Keterampilan Mengolah/Memroses } \\
\hline A. Menginferensi & HTP & $\mathrm{J}$ & $\mathrm{J}$ & НTP & $\mathrm{J}$ & HTP & HTP & $\mathrm{J}$ & HTP & $\mathrm{J}$ \\
\hline B. Memprediksi & HTP & HTP & HTP & HTP & HTP & HTP & HTP & HTP & $\mathrm{J}$ & $\mathrm{J}$ \\
\hline $\begin{array}{l}\text { C. Menyeleksi } \\
\text { prosedur }\end{array}$ & HTP & $\mathrm{J}$ & $\mathrm{J}$ & HTP & HTP & HTP & HTP & HTP & $\mathrm{J}$ & $\mathrm{J}$ \\
\hline
\end{tabular}

Keterangan Kategori:
S: Sering;
J: Jarang;
HTP: Hampir Tidak Pernah

Keterangan Wilayah:

$\begin{array}{llllll}\text { Kt. Yogya } & \text { : Kota Yogyakarta; } & \text { Yg } & \text { : Yogyakarta Barat; } & \text { Yt } & \text { : Yogyakarta Timur } \\ \text { Kb. Sleman } & \text { : Kabupaten Sleman; } & \text { Sl } & \text { : Sleman; } & \text { Kal } & \text { : Kalasan } \\ \text { Kb. Bantul } & \text { : Kabupaten Bantul; } & \text { Btl } & \text { : Bantul; } & \text { Piyu } & \text { : Piyungan } \\ \text { Kb. Gk } & \text { : Kabupaten Gunungkidul; } & \text { Wnsr } & \text { : Wonosari; } & \text { Pang } & \text { : Panggang } \\ \text { Kb. Kp } & \text { : Kabupaten Kulonprogo; } & \text { Peng } & \text { : Pengasih; } & \text { Klbw } & \text { : Kalibawang }\end{array}$

\section{Persepsi Peserta Didik}

Persepsi peserta didik kelas V dan VI dalam hal memperoleh pembelajaran yang mengembangkan kreativitas keterampilan proses sains yang berkaitan dengan aktivitas kehidup- an organisme disajikan pada Tabel 8, 9, 10, dan 11. Persepsi mereka didasarkan pada pengalaman yang selama ini mereka peroleh sejak mereka dibantu guru dalam belajam IPA sehingga didasarkan pada pengalaman sejak kelas I. Oleh 
karena itu, boleh jadi guru kelas IV atau guru kelas $\mathrm{V}$ menyatakan tidak mengajarkan keterampilan proses sains untuk mengembangkan kreativitas mereka, namun mereka menyatakan pernah diajar. Dalam hal ini adalah oleh guru lain pada kelas sebelumnya.

Tabel 8 dan 9 menyajikan pernyataan peserta didik dalam memperoleh pembelajaran yang mengembangkan kreativitas keterampilan proses sains yang dilakukan guru tanpa disertai dengan pemberian contoh, sedangkan Tabel 10 dan 11 menyajikan pernyataan peserta didik dalam memperoleh pembelajaran yang mengem- bangkan kreativitas keterampilan proses sains yang dilakukan guru dengan disertai pemberian contoh terlebih dahulu.

Tabel 8 menyajikan persepsi peserta didik kelas $\mathrm{V}$ dan Tabel 9 menyajikan persepsi peserta didik kelas VI, keduanya menunjukkan bahwa menurut peserta didik hampir tidak pernah atau jarang guru membelajarkan kreativitas keterampilan proses sains tanpa disertai dengan pemberian contoh, baik keterampilan proses sains yang termasuk keterampilan dasar maupun keterampilan mengolah/memroses.

Tabel 5. Pernyataan Guru Kelas IV IPA SD di DIY tentang Pembelajaran Pengembangan Kreativitas Keterampilan Proses Sains yang Berkaitan dengan Aspek Kehidupan Organisme yang Telah Diselenggarakan dengan Disertai Pemberian Contoh

\begin{tabular}{lcccccccccc}
\hline & \multicolumn{8}{c}{ Wilayah Unit Pelaksana Teknis } \\
\cline { 2 - 9 } $\begin{array}{l}\text { Aspek Keterampilan } \\
\text { Proses Sains }\end{array}$ & Kt. Yogya & Kb. Sleman & Kb. Bantul & \multicolumn{2}{c}{ Kb. Gk } & Kb. Kp \\
\cline { 2 - 9 } & Yb & Yt & Sl & Kal & Btl & Piyu & Wnsr & Pang & Peng & Klbw \\
\hline
\end{tabular}

\section{Keterampilan Dasar}

\begin{tabular}{|c|c|c|c|c|c|c|c|c|c|}
\hline $\begin{array}{l}\text { A. Melakukan peng- } \\
\text { amatan }\end{array}$ & $\mathrm{S}$ & $\mathrm{S}$ & $\mathrm{S}$ & $\mathrm{S}$ & $\mathrm{S}$ & $\mathrm{S}$ & $\mathrm{S}$ & $\mathrm{J}$ & $\mathrm{J}$ \\
\hline $\begin{array}{l}\text { B. Merekam data/infor- } \\
\text { masi }\end{array}$ & $\mathrm{S}$ & $\mathrm{S}$ & $\mathrm{S}$ & $\mathrm{S}$ & $\mathrm{S}$ & $\mathrm{S}$ & $\mathrm{S}$ & $\mathrm{J}$ & $\mathrm{J}$ \\
\hline C. Mengikuti instruksi & $\mathrm{S}$ & $\mathrm{S}$ & $\mathrm{S}$ & $\mathrm{S}$ & $\mathrm{S}$ & $\mathrm{S}$ & $\mathrm{S}$ & $\mathrm{J}$ & $\mathrm{S}$ \\
\hline D. Mengklasifikasi & S & S & S & S & S & S & S & S & S \\
\hline $\begin{array}{l}\text { E. Melakukan peng- } \\
\text { ukuran }\end{array}$ & $\mathrm{J}$ & $\mathrm{J}$ & $\mathrm{S}$ & $\mathrm{J}$ & $\mathrm{J}$ & $\mathrm{J}$ & $\mathrm{J}$ & $\mathrm{J}$ & $\mathrm{J}$ \\
\hline $\begin{array}{l}\text { F. Melakukan manipu- } \\
\text { lasi gerak }\end{array}$ & $\mathrm{J}$ & $\mathrm{S}$ & $\mathrm{S}$ & $\mathrm{S}$ & $\mathrm{S}$ & $\mathrm{S}$ & $\mathrm{S}$ & $\mathrm{J}$ & $\mathbf{J}$ \\
\hline $\begin{array}{l}\text { G. Menerapkan prosedur } \\
\text { penggunaan peralat- } \\
\text { an }\end{array}$ & $\mathrm{J}$ & $\mathrm{J}$ & $\mathrm{J}$ & $\mathrm{J}$ & $\mathrm{J}$ & $\mathrm{J}$ & $\mathrm{J}$ & $\mathrm{J}$ & $\mathrm{J}$ \\
\hline
\end{tabular}

\section{Keterampilan Mengolah/ Memroses}

\begin{tabular}{lllllllllll} 
A. Menginferensi & S & J & S & S & S & J & S & J & J & J \\
B. Memprediksi & J & J & S & S & S & S & S & J & J & J \\
C. Menyeleksi prosedur & S & J & S & J & J & J & J & J & J & J \\
\hline
\end{tabular}

Keterangan Kategori:
S: Sering;
J: Jarang;
HTP: Hampir Tidak Pernah

Keterangan Wilayah:

$\begin{array}{llllll}\text { Kt. Yogya } & \text { : Kota Yogyakarta; } & \text { Yg } & \text { :Yogyakarta Barat; Yt } & \text { : Yogyakarta Timur } \\ \text { Kb. Sleman } & \text { : Kabupaten Sleman; } & \text { Sl } & \text { : Sleman; } & \text { Kal } & \text { : Kalasan } \\ \text { Kb. Bantul } & \text { : Kabupaten Bantul; } & \text { Btl } & \text { : Bantul; } & \text { Piyu } & \text { : Piyungan } \\ \text { Kb. Gk } & \text { : Kabupaten Gunungkidul; Wnsr } & \text { : Wonosari; } & \text { Pang } & \text { : Panggang } \\ \text { Kb. Kp } & \text { : Kabupaten Kulonprogo; Peng } & \text { : Pengasih; } & \text { Klbw } & \text { : Kalibawang }\end{array}$


Tabel 6. Pernyataan Guru Kelas V IPA SD di DIY tentang Pembelajaran Pengembangan Kreativitas Keterampilan Proses Sains yang Berkaitan dengan Aspek Kehidupan Organisme yang Telah Diselenggarakan dengan Disertai Pemberian Contoh

\begin{tabular}{|c|c|c|c|c|c|c|c|c|c|c|}
\hline \multirow{3}{*}{$\begin{array}{l}\text { Aspek Keterampilan } \\
\text { Proses Sains }\end{array}$} & \multicolumn{10}{|c|}{ Wilayah Unit Pelaksana Teknis } \\
\hline & \multicolumn{2}{|c|}{ Kt. Yogya } & \multicolumn{2}{|c|}{ Kb. Sleman } & \multicolumn{2}{|c|}{ Kb. Bantul } & \multicolumn{2}{|c|}{ Kb. Gk } & \multicolumn{2}{|c|}{ Kb.Kp } \\
\hline & $\mathbf{Y b}$ & $\mathbf{Y t}$ & $\mathbf{S I}$ & Kal & Btl & Piyu & Wnsr & Pang & Peng & Klbw \\
\hline \multicolumn{11}{|l|}{ I. Keterampilan Dasar } \\
\hline $\begin{array}{l}\text { A. Melakukan } \\
\text { pengamatan }\end{array}$ & $\mathrm{S}$ & $S$ & $S$ & S & S & $S$ & S & $\mathrm{J}$ & $\mathrm{J}$ & $S$ \\
\hline $\begin{array}{l}\text { B. Merekam } \\
\text { data/informasi }\end{array}$ & $S$ & $S$ & S & S & S & $S$ & S & $\mathrm{J}$ & $\mathrm{J}$ & $\mathrm{J}$ \\
\hline C. Mengikuti instruksi & $\mathrm{S}$ & $\mathrm{S}$ & $\mathrm{S}$ & $\mathrm{S}$ & $\mathrm{S}$ & $\mathrm{S}$ & $\mathrm{S}$ & $\mathrm{S}$ & $\mathrm{S}$ & $\mathrm{S}$ \\
\hline D. Mengklasifikasi & $S$ & $S$ & $S$ & S & $S$ & S & S & $S$ & S & $\mathrm{J}$ \\
\hline $\begin{array}{l}\text { E. Melakukan } \\
\text { pengukuran }\end{array}$ & $\mathrm{J}$ & $\mathrm{J}$ & S & S & $\mathrm{J}$ & $\mathrm{J}$ & S & $\mathrm{J}$ & $\mathrm{J}$ & $\mathrm{J}$ \\
\hline $\begin{array}{l}\text { F. Melakukan } \\
\text { manipulasi gerak }\end{array}$ & $S$ & $S$ & $S$ & $S$ & $S$ & $S$ & $S$ & $\mathrm{~J}$ & $\mathrm{~J}$ & $\mathrm{~J}$ \\
\hline $\begin{array}{l}\text { G. Menerapkan } \\
\text { prosedur penggunaan } \\
\text { peralatan }\end{array}$ & $\mathrm{J}$ & $\mathrm{J}$ & $\mathrm{J}$ & $\mathrm{S}$ & $S$ & $S$ & $S$ & $\mathrm{~J}$ & $\mathrm{~J}$ & $S$ \\
\hline \multicolumn{11}{|c|}{ II. Keterampilan Mengolah/ Memroses } \\
\hline A. Menginferensi & $\mathrm{S}$ & $\mathrm{S}$ & $\mathrm{S}$ & $S$ & $S$ & $\mathrm{~J}$ & S & $\mathrm{J}$ & $\mathrm{J}$ & $\mathrm{J}$ \\
\hline B. Memprediksi & $\mathrm{S}$ & $\mathrm{S}$ & $\mathrm{S}$ & $\mathrm{S}$ & $\mathrm{S}$ & $\mathrm{J}$ & $\mathrm{S}$ & $\mathrm{J}$ & $\mathrm{J}$ & $\mathrm{J}$ \\
\hline C. Menyeleksi prosedur & $\mathrm{J}$ & $\mathrm{J}$ & $\mathrm{J}$ & $\mathrm{S}$ & $\mathrm{J}$ & $\mathrm{J}$ & $\mathrm{S}$ & $\mathrm{J}$ & $\mathrm{J}$ & $\mathrm{J}$ \\
\hline
\end{tabular}

Keterangan Kategori:

S: Sering; $\quad$ J: Jarang; $\quad$ HTP: Hampir Tidak Pernah

Keterangan Wilayah:

$\begin{array}{llllll}\text { Kt. Yogya } & \text { : Kota Yogyakarta; } & \text { Yg } & \text { : Yogyakarta Barat; Yt } & \text { : Yogyakarta Timur } \\ \text { Kb. Sleman } & \text { : Kabupaten Sleman; } & \text { Sl } & \text { :Sleman; } & \text { Kal } & \text { : Kalasan } \\ \text { Kb. Bantul } & \text { : Kabupaten Bantul; } & \text { Btl } & \text { : Bantul; } & \text { Piyu } & \text { : Piyungan } \\ \text { Kb. Gk } & \text { : Kabupaten Gunungkidul; Wnsr } & \text { : Wonosari; } & \text { Pang } & \text { : Panggang } \\ \text { Kb. Kp } & \text { : Kabupaten Kulonprogo; Peng } & \text { : Pengasih; } & \text { Klbw } & \text { : Kalibawang }\end{array}$

Tabel 7a. Pengalaman Guru Mengikuti Pendidikan-Latihan Tingkat Nasional/Regional dan Lokal/Inhouse Traning Berdasarkan UPT Dinas Pendidikan Sampel

\begin{tabular}{|c|c|c|c|c|c|c|c|c|c|c|c|c|}
\hline \multirow{3}{*}{ Uraian Kegiatan } & \multicolumn{12}{|c|}{ UPT Sampel } \\
\hline & \multicolumn{2}{|c|}{ Yogya Barat } & \multicolumn{2}{|c|}{$\begin{array}{l}\text { Yogya } \\
\text { Timur }\end{array}$} & \multicolumn{2}{|c|}{ Slaman } & \multicolumn{2}{|c|}{ Kalasan } & \multicolumn{2}{|c|}{ Bantul } & \multicolumn{2}{|c|}{ Piyungan } \\
\hline & IV & $\mathrm{V}$ & IV & $\mathrm{V}$ & IV & $\mathrm{V}$ & IV & $\mathrm{V}$ & IV & $\mathrm{V}$ & IV & $\mathrm{V}$ \\
\hline $\begin{array}{l}\text { 1. Diklat Nasinal atau } \\
\text { regional } \\
\text { 2. Diklat Lokal atau }\end{array}$ & 6 & 4 & 5 & 5 & 6 & 4 & 5 & 5 & 8 & 6 & 8 & 8 \\
\hline inhouse traning & 4 & 5 & 5 & 3 & 4 & 5 & 5 & 3 & 3 & 2 & 0 & 0 \\
\hline 3. Kombinasi $1 \& 2$ & 0 & 0 & 0 & 0 & 0 & 0 & 0 & 0 & 0 & 0 & 0 & 0 \\
\hline $\begin{array}{l}\text { 4. Belum pernah ikut } \\
\text { diklat }\end{array}$ & 10 & 11 & 10 & 12 & 10 & 11 & 10 & 12 & 9 & 12 & 12 & 12 \\
\hline Jumlah & 20 & 20 & 20 & 20 & 20 & 20 & 20 & 20 & 20 & 20 & 20 & 20 \\
\hline
\end{tabular}


Tabel 7b. Pengalaman Guru Mengikuti Pendidikan-Latihan Tingkat Nasional/Regional dan Lokal/Inhouse Traning Berdasarkan UPT Dinas Pendidikan Sampel

\begin{tabular}{lcccccccc}
\hline \multirow{2}{*}{ Uraian Kegiatan } & \multicolumn{9}{c}{ UPT Sampel } \\
\cline { 2 - 10 } & \multicolumn{2}{c}{ Wonosari } & \multicolumn{2}{c}{ Panggang } & Pengasih & \multicolumn{2}{c}{ Kalibawang } \\
\cline { 2 - 10 } & IV & V & IV & V & IV & V & IV & V \\
\hline 1. Diklat Nasinal atau regional & 1 & 4 & 5 & 14 & 4 & 3 & 5 & 5 \\
2. Diklat Lokal atau inhouse traning & 3 & 1 & 1 & 1 & 3 & 6 & 5 & 3 \\
3. Kombinasi 1 \& 2 & 0 & 0 & 0 & 0 & 2 & 1 & 0 & 0 \\
4. Belum pernah ikut diklat & 16 & 15 & 14 & 5 & 11 & 10 & 10 & 12 \\
\hline Jumlah & 20 & 20 & 20 & 20 & 20 & 20 & 20 & 20 \\
\hline
\end{tabular}

Sebagian besar guru ketika mengajar IPA sering membelajarkan kreativitas keterampilan proses sains dengan disertai pemberian contoh terlebih dahulu. Jika dibandingkan antara Tabel 10 dan Tabel 11, pernyataan yang sering lebih banyak pada Tabel 11, yakni berasal dari peserta didik kelas VI.

Jika Tabel 11 dicermati lebih lanjut, tampak bahwa peserta didik dari UPT Yogyakarta barat, Sleman, dan Kalasan saja yang menyatakan seluruh aspek keterampilan proses sains telah dibelajarkan oleh guru untuk mengembangkan kreativitas mereka dengan cara diberi contoh terlebih dahulu.

\section{Pembahasan}

\section{Analisis Keberagaman Persepsi}

Melihat data temuan di lapangan ternyata tetap ada perbedaan persepsi di antara para guru dalam menilai penting pengembangan kreativitas pada peserta didik khususnya yang berkaitan dengan keterampilan proses sains yang berkaitan dengan aktivitan kehidupan organisme.

Kategorisasi dilakukan dengan mempertimbangkan skor kumulatif. Jika skor kumulatif melebihi angka banyaknya butir kali jumlah guru, sebagai contoh suatu aspek keterampilan diungkap dengan 2 butir, maka dapat dinyatakan semua guru menyatakan tidak penting jika kumulatif skor sebesar 1 × 2 × 20 guru atau sebesar 40 karena untuk suatu butir yang dijawab dengan tidak penting diberi skor 1 . Jika lebih dari 40 berarti ada sebagian guru yang menyatakan kurang penting atau penting. Demikian pula jika suatu aspek keterampilan proses sains seperti keterampilan melakukan pengukuran diungkap dengan 14 butir maka dapat dinyatakan semua guru menyatakan tidak penting jika kumulatif skor sebesar 1 x 14 × 20 guru atau sebesar 280. Olerh karena itu, jika lebih besar dari 280 berarti ada sebagian guru yang menyatakan kurang penting (skor 2 untuk tiap butir) atau penting (skor 3 untuk tiap butir). Kuesioner yang dibagikan kepada guru, juga kepada peserta didik, untuk pembelajaran melalui pemberian contoh sudah disertai contoh kasus yang operasional yang dapat dipahami oleh mereka. Oleh karena itu, seharusnya tidak ada perbedaan persepsi akibat perbedaan tafsir terhadap instrumennya sendiri.

Kriteria bahwa kegiatan pembelajaran dinyatakan mengembangkan kreativitas dalam penelitian jika guru meminta peserta didik untuk berinisiatif melakukan atau memilih hal lain selain yang sudah ada di dalam contoh yang diberikan guru. Kriteria ini didasarkan pada pendapat Miller (2005:65) yang telah dikemukakan pada awal tulisan ini bahwa semua pemikiran atau kegiatan yang tidak meniru atau dapat digolongkan sebagai pemikiran atau kegiatan yang kreatif. Namun demikian, boleh jadi guru memiliki pandangan yang lain, sehingga tidak perlu sering diajarkan karena dibukan dinilai sekedar dari penting tidaknya, namun dikaitkan dengan kesulitan yang dapat muncul ketika guru menerapkannya. 
Tabel 8. Pernyataan Peserta Didik Kelas V IPA SD di DIY tentang Pembelajaran Pengembangan Kreativitas Keterampilan Proses Sains yang Berkaitan dengan Aspek Kehidupan Organisme yang Telah Diselenggarakan tanpa Disertai Pemberian Contoh

\begin{tabular}{|c|c|c|c|c|c|c|c|c|c|c|}
\hline \multirow{3}{*}{$\begin{array}{l}\text { Aspek Keterampilan } \\
\text { Proses Sains }\end{array}$} & \multicolumn{10}{|c|}{ Wilayah Unit Pelaksana Teknis } \\
\hline & \multicolumn{2}{|c|}{ Kt. Yogya } & \multicolumn{2}{|c|}{ Kb. Sleman } & \multicolumn{2}{|c|}{ Kb. Bantul } & \multicolumn{2}{|c|}{ Kb. Gk } & \multicolumn{2}{|c|}{ Kb.Kp } \\
\hline & $\mathbf{Y b}$ & $\mathbf{Y t}$ & SI & Kal & Btl & Piyu & Wnsr & Pang & Peng & Klbw \\
\hline \multicolumn{11}{|c|}{ I. $\quad$ Keterampilan Dasar } \\
\hline $\begin{array}{l}\text { A. Melakukan } \\
\text { pengamatan }\end{array}$ & HTP & HTP & HTP & HTP & HTP & HTP & HTP & HTP & HTP & HTP \\
\hline $\begin{array}{l}\text { B. Merekam } \\
\text { data/informasi }\end{array}$ & HTP & HTP & HTP & HTP & HTP & HTP & HTP & HTP & HTP & HTP \\
\hline $\begin{array}{l}\text { C. Mengikuti } \\
\text { instruksi }\end{array}$ & HTP & HTP & HTP & HTP & HTP & HTP & HTP & HTP & HTP & HTP \\
\hline D. Mengklasifikasi & HTP & HTP & HTP & HTP & HTP & HTP & HTP & HTP & HTP & HTP \\
\hline $\begin{array}{l}\text { E. Melakukan } \\
\text { pengukuran }\end{array}$ & HTP & HTP & HTP & HTP & HTP & HTP & HTP & HTP & HTP & HTP \\
\hline $\begin{array}{l}\text { F. Melakukan } \\
\text { manipulasi gerak }\end{array}$ & HTP & HTP & HTP & HTP & HTP & HTP & HTP & HTP & HTP & HTP \\
\hline 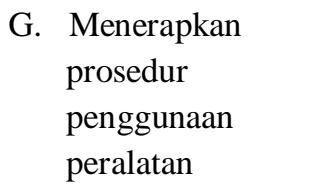 & HTP & HTP & HTP & HTP & HTP & HTP & HTP & HTP & HTP & HTP \\
\hline \multicolumn{11}{|c|}{ II. Keterampilan Mengolah/ Memroses } \\
\hline A. Menginferensi & HTP & HTP & HTP & HTP & HTP & HTP & HTP & HTP & HTP & HTP \\
\hline B. Memprediksi & HTP & HTP & HTP & HTP & HTP & HTP & HTP & HTP & HTP & HTP \\
\hline $\begin{array}{l}\text { C. Menyeleksi } \\
\text { prosedur }\end{array}$ & HTP & HTP & HTP & HTP & HTP & HTP & HTP & HTP & HTP & HTP \\
\hline
\end{tabular}

Keterangan Kategori:

P: Pernah; $\quad$ HTP: Hampir Tidak Pernah

Keterangan Wilayah:

$\begin{array}{llllll}\text { Kt. Yogya } & \text { : Kota Yogyakarta; } & \text { Yg } & \text { : Yogyakarta Barat; Yt } & \text { : Yogyakarta Timur } \\ \text { Kb. Sleman } & \text { : Kabupaten Sleman; } & \text { Sl } & \text { : Sleman; } & \text { Kal } & \text { : Kalasan } \\ \text { Kb. Bantul } & \text { : Kabupaten Bantul; } & \text { Btl } & \text { : Bantul; } & \text { Piyu } & \text { : Piyungan } \\ \text { Kb. Gk } & \text { : Kabupaten Gunungkidul; Wnsr } & \text { : Wonosari; } & \text { Pang } & \text { : Panggang } \\ \text { Kb. Kp } & \text { : Kabupaten Kulonprogo; Peng } & \text { : Pengasih; } & \text { Klbw } & \text { : Kalibawang }\end{array}$

Sebagaimana dikemukakan oleh Ander-

lajaran, Dettmer (2006:70-78) menyatakan bahson \& Krathwohl (2001:31) bahwa berkreasi merupakan kemampuan menggunakan elemenelemen untuk membentuk sesuatu yang lebih koheren atau fungsi yang utuh seperti menggunakan elemen untuk membentuk suatu pola atau struktur baru melalui proses generating/ hypothesizing, planing/designing, dan producing/contructing. Dengan demikian, mengkreasi tidak akan dapat dilakukan oleh seseorang yang tidak memiliki elemen pengetahuan di dalam benaknya. Sementara dari segi model pembewa pengembangan kreativitas hanya akan efektif jika menggunakan model pembelajaran ideasional (ideational learning).

Kekhawatiran kedua adalah adanya hal yang selalu membayangi guru akan pentingnya menyiapkan peserta didik harus lulus Ujian Nasional (UN). Pembelajaran yang efektif untuk menyiapkan peserta didik lulus UN adalah melalui pembelajaran berbasis standar yang tentu saja berbeda dengan pembelajaran untuk mengembangkan kreativitas. 
Tabel 9. Pernyataan Peserta Didik Kelas VI IPA SD di DIY tentang Pembelajaran Pengembangan Kreativitas Keterampilan Proses Sains yang Berkaitan dengan Aspek Kehidupan Organisme yang Telah Diselenggarakan tanpa Disertai Pemberian Contoh

\begin{tabular}{|c|c|c|c|c|c|c|c|c|c|c|}
\hline \multirow{3}{*}{$\begin{array}{l}\text { Aspek } \\
\text { Keterampilan } \\
\text { Proses Sains }\end{array}$} & \multicolumn{10}{|c|}{ Wilayah Unit Pelaksana Teknis } \\
\hline & \multicolumn{2}{|c|}{ Kt. Yogya } & \multicolumn{2}{|c|}{ Kb. Sleman } & \multicolumn{2}{|c|}{ Kb. Bantul } & \multicolumn{2}{|c|}{ Kb. Gk } & \multicolumn{2}{|c|}{ Kb.Kp } \\
\hline & $\mathbf{Y b}$ & $\mathbf{Y t}$ & Sl & Kal & Btl & Piyu & Wnsr & Pang & Peng & Klbw \\
\hline \multicolumn{11}{|c|}{ I. Keterampilan Dasar } \\
\hline $\begin{array}{l}\text { A. Melakukan } \\
\text { pengamatan }\end{array}$ & HTP & HTP & HTP & HTP & HTP & HTP & HTP & HTP & HTP & HTP \\
\hline $\begin{array}{l}\text { B. Merekam data/in } \\
\text { formasi }\end{array}$ & HTP & HTP & HTP & HTP & $\mathrm{P}$ & HTP & HTP & HTP & HTP & HTP \\
\hline $\begin{array}{l}\text { C. Mengikuti in- } \\
\text { struksi }\end{array}$ & HTP & HTP & HTP & HTP & HTP & HTP & HTP & HTP & HTP & HTP \\
\hline D. Mengklasifikasi & HTP & HTP & HTP & HTP & HTP & HTP & HTP & HTP & HTP & HTP \\
\hline $\begin{array}{l}\text { E. Melakukan } \\
\text { pengukuran }\end{array}$ & HTP & HTP & HTP & HTP & HTP & HTP & HTP & HTP & HTP & HTP \\
\hline $\begin{array}{l}\text { F. Melakukan ma- } \\
\text { nipulasi gerak }\end{array}$ & HTP & HTP & HTP & HTP & HTP & HTP & HTP & HTP & HTP & HTP \\
\hline $\begin{array}{l}\text { G. Menerapkan } \\
\text { prosedur peng- } \\
\text { gunaan peralatan }\end{array}$ & HTP & HTP & HTP & HTP & $\mathrm{P}$ & HTP & HTP & HTP & HTP & HTP \\
\hline \multicolumn{11}{|c|}{ II. Keterampilan Mengolah/ Memroses } \\
\hline D. Menginferensi & HTP & HTP & HTP & HTP & HTP & HTP & HTP & HTP & HTP & HTP \\
\hline E. Memprediksi & HTP & HTP & HTP & HTP & HTP & HTP & HTP & HTP & HTP & HTP \\
\hline $\begin{array}{l}\text { F. Menyeleksi } \\
\text { prosedur }\end{array}$ & HTP & HTP & HTP & HTP & HTP & HTP & HTP & HTP & HTP & НTP \\
\hline
\end{tabular}

\section{Keterangan Kategori:}

P: Pernah;

HTP: Hampir Tidak Pernah

Keterangan Wilayah:

$\begin{array}{llllll}\text { Kt. Yogya } & \text { : Kota Yogyakarta; } & \text { Yg } & \text { : Yogyakarta Barat; Yt } & \text { : Yogyakarta Timur } \\ \text { Kb. Sleman } & \text { : Kabupaten Sleman; } & \text { Sl } & \text { : Sleman; } & \text { Kal } & \text { : Kalasan } \\ \text { Kb. Bantul } & \text { : Kabupaten Bantul; } & \text { Btl } & \text { : Bantul; } & \text { Piyu } & \text { : Piyungan } \\ \text { Kb. Gk } & \text { : Kabupaten Gunungkidul; Wnsr } & \text { : Wonosari; } & \text { Pang } & \text { : Panggang } \\ \text { Kb. Kp } & \text { : Kabupaten Kulonprogo; Peng } & \text { : Pengasih; } & \text { Klbw } & \text { : Kalibawang }\end{array}$

Berkaitan dengan pembelajaran kreativitas, Burke (2007:58-63) menyatakan bahwa mempertimbangkan kemungkinan untuk menyeimbangkan pembelajaran berbasis standar dan pembelajaran untuk mengembangkan kreativitas menjadi menarik karena antara pembelajaran berbasis standar dan pembelajaran untuk mengembangkan kreativitas merupakan dua spektrum yang sifatnya berkebalikan. Adanya tindakan guru yang hanya mengajar agar peserta didik lulus ujian menunjukkan bahwa guru tersebut menyelenggarakan pembelajaran yang lebih diorientasikan agar peserta didik dapat memahami tes atau diistilahkan sebagai teaching for the test (Jehlen, 2007:29-34). Pembelajaran IPA yang kreatif pada dasarnya peserta didik diminta untuk melakukan penemuan atau inkuiri (inquiry) secara terbuka, atau mengerjakan tugas-tugas yang berkait dengan penyelidikan, sehingga peserta didik melakukan kegiatan seperti kegiatan kreatif yang dilakukan oleh ilmuwan dalam melakukan riset ilmiah. Pendekatan kognitif menyatakan bahwa pembelajaran dapat menyesuaikan diri dengan mengembangkan pola penalaran yang kreatif (Kind \& Kind (2007:1-37) 
Tabel 10. Pernyataan Peserta Didik Kelas V IPA SD di DIY tentang Pembelajaran Pengembangan Kreativitas Keterampilan Proses Sains yang Berkaitan dengan Aspek Kehidupan Organisme yang Telah Diselenggarakan dengan Disertai Pemberian Contoh

\begin{tabular}{|c|c|c|c|c|c|c|c|c|c|c|}
\hline \multirow{3}{*}{$\begin{array}{l}\text { Aspek Keterampilan } \\
\text { Proses Sains }\end{array}$} & \multicolumn{10}{|c|}{ Wilayah Unit Pelaksana Teknis } \\
\hline & \multicolumn{2}{|c|}{$\begin{array}{c}\text { Kt. } \\
\text { Yogya }\end{array}$} & \multicolumn{2}{|c|}{$\begin{array}{l}\text { Kb. } \\
\text { Sleman }\end{array}$} & \multicolumn{2}{|c|}{$\begin{array}{c}\text { Kb. } \\
\text { Bantul }\end{array}$} & \multicolumn{2}{|c|}{ Kb. Gk } & \multicolumn{2}{|c|}{ Kb.Kp } \\
\hline & Yb & Yt & SI & Kal & Btl & Piyu & Wnsr & Pang & Peng & Klbw \\
\hline \multicolumn{11}{|l|}{ I. Keterampilan Dasar } \\
\hline A. Melakukan pengamatan & $\mathrm{P}$ & $\mathrm{P}$ & $\mathrm{P}$ & $\mathrm{P}$ & $\mathrm{P}$ & $\mathrm{P}$ & $\mathrm{P}$ & $\mathrm{P}$ & $\mathrm{P}$ & $\mathrm{P}$ \\
\hline B. Merekam data/informasi & $\mathrm{P}$ & $\mathrm{P}$ & $\mathrm{P}$ & $\mathrm{P}$ & $\mathrm{P}$ & $\mathrm{P}$ & $\mathrm{P}$ & $\mathrm{P}$ & $\mathrm{P}$ & $\mathrm{P}$ \\
\hline C. Mengikuti instruksi & $\mathrm{P}$ & $\mathrm{P}$ & $\mathrm{P}$ & $\mathrm{P}$ & $\mathrm{P}$ & $\mathrm{P}$ & $\mathrm{P}$ & $\mathrm{P}$ & $\mathrm{P}$ & $\mathrm{P}$ \\
\hline D. Mengklasifikasi & $\mathrm{P}$ & $\mathrm{P}$ & $\mathrm{P}$ & $\mathrm{P}$ & $\mathrm{P}$ & $\mathrm{P}$ & $\mathrm{P}$ & $\mathrm{P}$ & $\mathrm{P}$ & $\mathrm{P}$ \\
\hline E. Melakukan pengukuran & $\mathrm{P}$ & $\mathrm{P}$ & $\mathrm{P}$ & $\mathrm{P}$ & HTP & $\mathrm{P}$ & $\mathrm{P}$ & HTP & HTP & HTP \\
\hline $\begin{array}{l}\text { F. Melakukan manipulasi } \\
\text { gerak }\end{array}$ & $\mathrm{P}$ & $\mathrm{P}$ & $\mathrm{P}$ & $\mathrm{P}$ & $\mathrm{P}$ & $\mathrm{P}$ & $\mathrm{P}$ & $\mathrm{P}$ & $\mathrm{P}$ & $\mathrm{P}$ \\
\hline $\begin{array}{l}\text { G. Menerapkan prosedur } \\
\text { penggunaan peralatan }\end{array}$ & $\mathrm{P}$ & $\mathrm{P}$ & $\mathrm{P}$ & $\mathrm{P}$ & HTP & $\mathrm{P}$ & $\mathrm{P}$ & HTP & HTP & HTP \\
\hline \multicolumn{11}{|c|}{ II. Keterampilan Mengolah/Memroses } \\
\hline A. Menginferensi & $\mathrm{P}$ & $\mathrm{P}$ & $\mathrm{P}$ & $\mathrm{P}$ & $\mathrm{P}$ & $\mathrm{P}$ & $\mathrm{P}$ & $\mathrm{P}$ & HTP & $\mathrm{P}$ \\
\hline B. Memprediksi & $\mathrm{P}$ & $\mathrm{P}$ & $\mathrm{P}$ & $\mathrm{P}$ & HTP & $\mathrm{P}$ & $\mathrm{P}$ & $\mathrm{P}$ & $\mathrm{P}$ & $\mathrm{P}$ \\
\hline C. Menyeleksi prosedur & $\mathrm{P}$ & $\mathrm{P}$ & $\mathrm{P}$ & $\mathrm{P}$ & $\mathrm{P}$ & $\mathrm{P}$ & $\mathrm{P}$ & HTP & HTP & НТP \\
\hline
\end{tabular}

Keterangan Kategori:

P: Pernah; $\quad$ HTP: Hampir Tidak Pernah

Keterangan Wilayah:

$\begin{array}{llllll}\text { Kt. Yogya } & \text { : Kota Yogyakarta; } & \text { Yg } & \text { : Yogyakarta Barat; Yt } & \text { : Yogyakarta Timur } \\ \text { Kb. Sleman } & \text { : Kabupaten Sleman; } & \text { Sl } & \text { : Sleman; } & \text { Kal } & \text { : Kalasan } \\ \text { Kb. Bantul } & \text { : Kabupaten Bantul; } & \text { Btl } & \text { : Bantul; } & \text { Piyu } & \text { : Piyungan } \\ \text { Kb. Gk } & \text { : Kabupaten Gunungkidul; Wnsr } & \text { : Wonosari; } & \text { Pang } & \text { : Panggang } \\ \text { Kb. Kp } & \text { : Kabupaten Kulonprogo; Peng } & \text { : Pengasih; } & \text { Klbw } & \text { : Kalibawang }\end{array}$

Peserta didik IPA di sekolah adalah 'pemikir sederhana', oleh karenanya cenderung boleh untuk menggunakan proses ilmiah manapun dengan cara yang berbeda dari para ilmuwan. Guru harus merangsang agar peserta didik mampu berinisiatif sendiri menerapkan setiap aspek keterampilan proses sains, termasuk berinisiatif menemukan kemungkinan kesalahan ketika menerapkannya. Media akan sangat membantu pengembangan kreativitas. Hasil penelitian Williams (2013:43) menunjukkan bahwa dengan media "Slippery Scence" dapat mendorong peserta didik menemukan gagasan untuk membalik/memutar eksperimen biasa ke

dalam peluang yang lebih kreatif dan mengesankan.

Tidak berkembangnya kreativitas pada peserta didik juga akibat kebiasaan cara bertanya guru. Pertanyaan yang bersifat divergen adalah pertanyaan yang tidak akan memberikan jawaban "ya" atau "tidak" namun yang memberikan banyak kemungkinan jawaban sehingga merupakan pertanyaan yang bersifat terbuka (open-ended) (Croom \& Stair, 2005:12-14) Sebaliknya pertanyaan yang bersifat konvergen bercirikan memiliki satu jawaban yang benar dan merupakan pertanyaan yang bersifat tertutup. 
Tabel 11. Pernyataan Peserta Didik Kelas VI IPA SD di DIY tentang Pembelajaran Pengembangan Kreativitas Keterampilan Proses Sains yang Berkaitan dengan Aspek Kehidupan Organisme yang Telah Diselenggarakan dengan Disertai Pemberian Contoh

\begin{tabular}{|c|c|c|c|c|c|c|c|c|c|c|}
\hline \multirow{3}{*}{$\begin{array}{l}\text { Aspek Keterampilan } \\
\text { Proses Sains }\end{array}$} & \multicolumn{10}{|c|}{ Wilayah Unit Pelaksana Teknis } \\
\hline & \multicolumn{2}{|c|}{$\begin{array}{c}\text { Kt. } \\
\text { Yogya }\end{array}$} & \multicolumn{2}{|c|}{$\begin{array}{l}\text { Kb. } \\
\text { Sleman }\end{array}$} & \multicolumn{2}{|c|}{$\begin{array}{c}\text { Kb. } \\
\text { Bantul }\end{array}$} & \multicolumn{2}{|c|}{ Kb. Gk } & \multicolumn{2}{|c|}{ Kb.Kp } \\
\hline & $\mathbf{Y b}$ & $\mathbf{Y t}$ & SI & Kal & Btl & Piyu & Wnsr & Pang & Peng & Klbw \\
\hline \multicolumn{11}{|l|}{ I. Keterampilan Dasar } \\
\hline $\begin{array}{l}\text { A. Melakukan pengamat- } \\
\text { an }\end{array}$ & $\mathrm{P}$ & $\mathrm{P}$ & $\mathrm{P}$ & $\mathrm{P}$ & $\mathrm{P}$ & $\mathrm{P}$ & $\mathrm{P}$ & $\mathrm{P}$ & $\mathrm{P}$ & $\mathrm{P}$ \\
\hline $\begin{array}{l}\text { B. Merekam data/infor- } \\
\text { masi }\end{array}$ & $\mathrm{P}$ & $\mathrm{P}$ & $\mathrm{P}$ & $\mathrm{P}$ & $\mathrm{P}$ & $\mathrm{P}$ & $\mathrm{P}$ & $\mathrm{P}$ & $\mathrm{P}$ & $\mathrm{P}$ \\
\hline C. Mengikuti instruksi & $\mathrm{P}$ & $\mathrm{P}$ & $\mathrm{P}$ & $\mathrm{P}$ & $\mathrm{P}$ & $\mathrm{P}$ & $\mathrm{P}$ & $\mathrm{P}$ & $\mathrm{P}$ & $\mathrm{P}$ \\
\hline D. Mengklasifikasi & $\mathrm{P}$ & $\mathrm{P}$ & $\mathrm{P}$ & $\mathrm{P}$ & $\mathrm{P}$ & $\mathrm{P}$ & $\mathrm{P}$ & $\mathrm{P}$ & $\mathrm{P}$ & $\mathrm{P}$ \\
\hline E. Melakukan pengukuran & $\mathrm{P}$ & HTP & $\mathrm{P}$ & $\mathrm{P}$ & HTP & НTP & HTP & HTP & $\mathrm{P}$ & HTP \\
\hline $\begin{array}{l}\text { F. Melakukan manipula- } \\
\text { si gerak }\end{array}$ & $\mathrm{P}$ & $\mathrm{P}$ & $\mathrm{P}$ & $\mathrm{P}$ & $\mathrm{P}$ & $\mathrm{P}$ & $\mathrm{P}$ & $\mathrm{P}$ & $\mathrm{P}$ & $\mathrm{P}$ \\
\hline $\begin{array}{l}\text { G. Menerapkan prosedur } \\
\text { penggunaan peralatan }\end{array}$ & $\mathrm{P}$ & $\mathrm{P}$ & $\mathrm{P}$ & $\mathrm{P}$ & HTP & $\mathrm{P}$ & HTP & HTP & HTP & $\mathrm{P}$ \\
\hline \multicolumn{11}{|c|}{ II. Keterampilan Mengolah/ Memroses } \\
\hline A. Menginferensi & $\mathrm{P}$ & $\mathrm{P}$ & $\mathrm{P}$ & $\mathrm{P}$ & $\mathrm{P}$ & $\mathrm{P}$ & $\mathrm{P}$ & HTP & $\mathrm{P}$ & $\mathrm{P}$ \\
\hline B. Memprediksi & $\mathrm{P}$ & $\mathrm{P}$ & $\mathrm{P}$ & $\mathrm{P}$ & $\mathrm{P}$ & $\mathrm{P}$ & $\mathrm{P}$ & $\mathrm{P}$ & $\mathrm{P}$ & $\mathrm{P}$ \\
\hline C. Menyeleksi prosedur & $\mathrm{P}$ & $\mathrm{P}$ & $\mathrm{P}$ & $\mathrm{P}$ & $\mathrm{P}$ & $\mathrm{P}$ & HTP & HTP & $\mathrm{P}$ & $\mathrm{P}$ \\
\hline
\end{tabular}

Keterangan Kategori:

P: Pernah;

HTP: Hampir Tidak Pernah

\section{Keterangan Wilayah:}

$\begin{array}{llllll}\text { Kt. Yogya } & \text { : Kota Yogyakarta; } & \text { Yg } & \text { : Yogyakarta Barat; Yt } & \text { : Yogyakarta Timur } \\ \text { Kb. Sleman } & \text { : Kabupaten Sleman; } & \text { Sl } & \text { : Sleman; } & \text { Kal } & \text { : Kalasan } \\ \text { Kb. Bantul } & \text { : Kabupaten Bantul; } & \text { Btl } & \text { : Bantul; } & \text { Piyu } & \text { : Piyungan } \\ \text { Kb. Gk } & \text { : Kabupaten Gunungkidul; Wnsr } & \text { : Wonosari; } & \text { Pang } & \text { : Panggang } \\ \text { Kb. Kp } & \text { : Kabupaten Kulonprogo; Peng } & \text { : Pengasih; } & \text { Klbw } & \text { : Kalibawang }\end{array}$

Kemungkinan berikutnya guru punya anggapan bahwa hanya anak yang cerdas saja yang kreatif. Anak-anak pedesaan seperti di UPT Kalibawang dapat dipersepsi oleh guru tidak cocok untuk dikembangkan kreativitasnya. Akibatnya guru di UPT tersebut jarang melakukannya. Padahal tidak selalu anak cerdas pasti kreatif. Hasil penelitian Ferrando et al. (2005:2150) menunjukkan adanya korelasi yang rendah antara kreativitas dan intelegensi. Peserta didik dengan IQ yang tinggi tidak semuanya lebih kreatif. Menurut Cromie (2007: 1) tidak semua studi menunjukkan adanya korelasi antara tingkatan IQ dan kreativitas. Beberapa studi menunjukkan bahwa peningkatan kreativitas sejalan dengan peningkatan IQ sampai dengan IQ

setinggi 120. Kyung Hee Kim (2005:1) melaporkan bahwa hasil metaanalisis 447 koefisien korelasi menunjukkan banyak skor tes kreativitas yang tidak ada hubungannya dengan skor IQ, namun banyak pula yang menunjukkan hubungannya. Miftachuddin (2006:264) menyatakan jangan sampai penghormatan peserta didik kepada guru memasung kreativitasnya. Gurulah yang bertanggung jawab untuk mengembangkan kreativitas peserta didik. Untuk mengubah keyakinan guru ke hal baru butuh waktu yang lama dan harus dibantu dengan program pengembangan keprofesionalan guru (Hidayat, 2007:79).

Kemungkinan terakhir bahwa memang guru tidak memiliki pengetahuan yang cukup 
untuk membantu pengembangan kreativitas peserta didik. Guru mengajarkan segala sesuatu secara rutin, dalam arti mengikuti prosedur atau konsep yang sudah ada di dalam buku. Michalko (2000:18-21) menyatakan bahwa pemikiran yang mempola memungkinkan mengerjakan tugas rutin dengan cepat dan teliti namun akan menyulitkan seseorang untuk memperoleh gagasan baru dan solusi kreatif bila menghadapi permasalahan, terutama permasalahan yang tidak biasa. dengan cara memodifikasi pola lama menjadi sesuatu yang baru. Artikel yang ditulis oleh Rawat dkk. (2012:264-275) juga membantah bahwa pengembangan kreativitas berhubungan erat kepada pengembangan keterampilan untuk membentuk pertimbangan yang sesuai di dalam situasi yang berbeda. Dengan kata lain pengembangan kreativitas harus dibelajarkan seawal mungkin kepada peserta didik.

Perbedaan persepsi antara guru dan peserta didik di beberapa UPT tertentu dimana guru menyatakan sering membelajarkan pengembangan kreativitas keterampilan sains namun peserta didik menyatakan hampir tidak pernah merupakan perbedaan persepsi yang dapat terjadi dapat diakibatkan karena peserta didik diminta mengekspresikan persepsinya sejak mereka belajar IPA di SD. Boleh jadi meskipun guru kelas IV atau kelas V menyatakan sering mengajarkannya namun guru merasa lebih banyak tidaknya terbantu selama mereka belajar IPA sejak awal. Dari butir yang ditanyakan umumnya peserta didik tidak pernah dibelajarkan melakukan pengukuran dengan peralatan yang mutakhir seperti tensimeter digital sehingga boleh jadi tidak semua guru di UPT sampel mengaitkan pengembangan kreativitas dengan keterampilan pengukuran.

\section{PENUTUP}

Berdasarkan temuan di lapangan melalui survei terhadap sampel yang terdiri atas 400 guru kelas IV dan V serta 1200 grup peserta didik dari 10 UPT yang ada di lima kabupaten/ kota di DIY dapat ditarik disimpulkan bahwa hampir semua guru sampel menyatakan bahwa pengembangan keterampilan proses sains yang berkaitan dengan aspek kehidupan organisme penting untuk diajarkan pada peserta didik. Guru hampir tidak pernah atau jarang membelajarkan kreativitas keterampilan proses sains tanpa disertai dengan pemberian contoh. Bahkan, guru kelas IV dari UPT Wonosari menyatakan hampir tidak pernah mengajarkannya, baik untuk aspek keterampilan dasar maupun keterampilan mengolah/memroses. Sebagian guru menyatakan sering membelajarkan kreativitas keterampilan proses sains dengan cara disertai pemberian contoh terlebih dahulu, meskipun sebagian ada pula yang menyatakan jarang melakukannya. Banyak hal yang dapat melatarbelakangi sikap dan tindakan guru mengembangkan kreativitas keterampilan proses sains, namun tampaknya kurang berkait jika dihubungkan dengan pengalaman mengikuti diklat. Tidak ada satupun guru yang melaporkan pernah mengikuti diklat pengembangan kreativitas. Peserta didik juga melaporkan bahwa berdasarkan pengalaman selama belajar IPA sampai saat menduduki kelas sekarang (kelas V dan VI) hampir tidak pernah diberi pembelajaran untuk mengembangkan kreativitas mereka tanpa disertai contoh terlebih dahulu oleh guru.

Rekomendasi yang dapat diberikan adalah bahwa para guru di lapangan perlu memperoleh pendidikan dan pelatihan untuk menyelenggarakan pembelajaran yang berorientasi untuk mengembangkan kreativitas pada peserta didik. Untuk itu, Dinas Pendidikan dapat bekerjasama dengan perguruan tinggi untuk merealisasikannya.

\section{UCAPAN TERIMA KASIH}

Ucapan terima kasih peneliti sampaikan kepada Kepala Direktorat Penelitian dan Pengabdian Kepada Masryarakat, Ditjen Dikti, Kemendikbud yang telah memberikan dana untuk menyelenggarakan penelitian ini melalui hibah kompetensi pada tahun pertama.

\section{DAFTAR PUSTAKA}

Anderson, Orin W. \& Krathwohl, David R. (ed). 2001. A Taxonomy for Learning, Teaching, and Assessing: A Revision of Blomm's Taxonomy of Educational Objectives. New York: Longman. 
Burke-Adam, Angela. 2007. "The Benefits of Equalizing Standards and Creativity: Discovering a Balance in Instruction" dalam Gifted Child Today, 30, 1, pp. 58-63. (Diunduh 29 Oktober 2007).

Edwards, Clifford H. 1997. "Promoting Student Inquiry", dalam The Science Teacher; Oct 1997; 64,7. ProQuest Education Journals, pp. 18-23.

Carin, Arthur A. \& Sund, Robert B. 1989. Teaching Science Through Discovery. Columbus: Merrill Publishing Company.

Chiapetta, Eugene L. 1997. "Inquiry-Based Science", dalam The Science Teacher. Oct 1997; 64, 7. ProQuest Education Journals, 22-26. (Diunduh 6 Agustus 2007).

Cochran-Smith, Marilyn \& Lytle, Susan L. 2006. "Troubling Images of Teaching in No Child Left Behind", dalam Harvard Educational Review. Cambridge: Winter 2006. Vol. 76, Iss. 4; pp. 668-700 (Diunduh 19 Agustus 2007).

Cromie, William J. 2007. Creativity Tied to Mental Illness: Irrelevance Can Make You Mad. (http://www.news.harvard. edu/ gazette/...reativity.html. Diunduh 29 Januari 2009).

Croom, Barry. \& Stair, Kristin. 2005. "Getting from Q to A: Effective questioning for effective learning", dalam The Agricultural Education Magazine, 78, 1, 12-14. (Diunduh 19 Agustus 2007).

Depdiknas. 2006. Lampiran Peraturan Menteri Pendidikan Nasional Republik Indonesia Nomor 22 Tahun 2006 Tentang Standar Isi untuk Satuan Pendidikan Dasar dan Menengah.

Dettmer, Peggy. 2006. "New Blooms in Established Fields: Four Domains of Learning and Doing" Roeper Review, 28, 2, 70-78. (Diunduh 28 Oktober 2007).
Ferrando, M., Prieto, M.D., Ferrandiz, C. \& Sanchesz, C. 2005. "Intelligence and Creativity", dalam Electronic Journal of Reseacrch in Education, ISSN: 16962095, 7, 3(3): 21-50. (Diunduh 29 Januari 2009).

Iceng Hidayat. 2007. "Peranan Keyakinan Guru terhadap Hakikat dan Belajar Sains dalam Pengembangan Profesionalisme", dalam Cakrawala Pendidikan: Jurnal Ilmiah Pendidikan, Februari 2007. Th XXVI, No.1. Hlmn: 63-82.

Jehlen, Alain. 2007. Testing How The Sausage is Made. NEA Today, 25 (7): 29-34. (Diunduh 29 Januari 2009).

Kim, Kyung-Hee. 2005. Can Only Intelligent People be Creative? A Meta-Analysis. The Journal of Secondary Gifted Education, (16), (2-3): 57-66. (Diunduh 28 Oktober 2007).

Kind, Per Morten \& Kind, Vanessa. 2007. "Creativity in science education: Perspectives and challenges for developing school science" dalam Studies in Science Education, 43, 1-37. (Diunduh 28 Oktober 2007).

Michalko, Michael. 2000. "Four Steps toward creative Thinking", dalam The Futurist; May/Jun 2000; 34, 18-21; ProQuest Education Journals. (Diunduh tanggal 19 Agustus 2007).

Miftachuddin. 2006. "Konsep Profil Guru dan Siswa (Mengenal Pemikiran Al-Zarnuji dalam Ta'lim Al-Muta'allim dan Relevansinya)", dalam Cakrawala Pendidikan: Jurnal Ilmiah Pendidikan, Juni 2006. Th XXV, No. 2. Hlmn: 247-267.

Miller, John L. 2005. Mind Magic: How to Develop the 3 Components of Intelligence that Matter Most in Today's World.

Rawat, Khalid Jamil; Qazi, Wasim; Hamid, Shams. 2012. "Creativity And Educa- 
tion", dalam Academic Research International 2.2 (Mar/Apr 2012): 264-275. (Diunduh Tanggal 6 Juli 2013).

Towle, Albert. 1989. Modern Biology. Austin: Holt, Rinehart and Winston.
Williams, James. 2013. "Science - Creativity is All in the Mind: Resources", dalam The Times Educational Supplement 5030 (Feb 8, 2013): 43. (Diunduh Tanggal 6 Juli 2013). 